\title{
Housing Informality of Fulani Nomads in Ogbomoso Region, Nigeria
}

\author{
ABOLADE, O; *ADIGUN F. O, OLUNIRAN D.D, ADETUNJI M.A and IGE J.O. \\ Department of Urban and Regional Planning, Faculty of Environmental Sciences \\ Ladoke Akintola University of Technology, PMB 4000, Ogbomoso, Oyo State Nigeria \\ *Corresponding Author
}

\begin{abstract}
Against the background negativities associated with informal housing particularly in Fulani nomadic settlement, this paper appraises housing characteristics of Fulani nomads in Ogbomoso region. Purposive sampling technique was employed to select Fulani's five host communities each from the urban and rural part of the region. Based on direct housing counting and estimates given by community leaders, a total number of six hundred and forty-seven (647) residents across the selected host communities were randomly selected for questionnaire administration. In each of the selected Fulani settlement, interview was conducted with the head of the clan or adult and Focus Group Discussion served as general platform for all other available Fulanis. Content analysis using thematic approach was employed to analyze such qualitative information. Using Likert Scale Rating, an index Shared Facilities Index (SFI) was developed to measure availability and functionality of shared facilities. The study reveals that Fulani housing satisfies primarily shelter housing with an indigenous design of cone shaped although some are built with modern building materials. There occupancy ratio within building satisfy family cohesion rather than two people per habitable room standard. Some of the facilities like toilet were not readily available for use and not functional. The result of Likert Scale rating shows lowest functionality index for health center (SFI 1.67), secondary school (SFI1.45) water supply (SFI1.40) electricity (SFI1.03) and public toilet (SF11.00). The study concludes that informal settlement is an attribute of nomads. This manifested in spatial manifestation of nomadic settlement in Ogbomoso region. The study therefore recommends that quantitative and qualitative residential development should be facilitated through Fulani Housing Scheme. Coupled with this, there should be adequate provision of basic infrastructural facilities. This should be accessible, functional and regularly maintained. Through these measures, the livability of Fulani nomadic will be improved and sustained.
\end{abstract}

DOI: $10.7176 /$ JAAS/58-07

Publication date:September $30^{\text {th }} 2019$

\section{Introduction}

Housing is not just a roof over one's head; it is the conjunction of dwelling, home, immediate environment and the community (WHO, 2004). Nomads housing contradicts the description of standard housing. Most dwelling of their units are in poor conditions, without basic infrastructure like electricity, portable water supply, sanitary facilities among others. Consequently, housing as a tool of human settlement development is an age long challenge to many societies with no exemption to Fulani nomads' settlement within Ogbomoso region.

The emergent interest in informality globally is transforming, appearing in many contexts, new spheres and guises. As such informality is overarching into informal urbanization, informal economy and informal housing. Although, a generally accepted interpretation of the genesis of all informal activities is rooted in operating beyond the prevailing regulatory systems (Victor, 2007). In fact, the assertion of Bassett et al, (2003) marked that a phenomenon of rapid urbanization in Africa has been the proliferation and uncontrolled spread of so-called "spontaneous" or "informal settlements" built by immigrants to meet their shelter needs. Besides, informal settlements cover issues such as illegal occupation of lands, houses built on lands not intended for that purpose, housing that do not have planning permission and houses that do not conform to the laid down building regulations of an area (UN Habitat, 2003; Fekade, 2000).

Informal settlement, according to Sietchiping (2005) as cited by Fikreselassie, (2011) refers to collection of buildings associated with low standard of living, overcrowding, acute shortage of basic physical, social services and infrastructure, high environmental and health threat, faulty alignment of streets, social composition (especially in relation to migration) and unfavourable socio-economic and living conditions that are 
non- compliant to planning regulations and legal tenure system. Evidently, it cannot be gainsaid that a critical appraisal into informal settlement indicates a colossal trend with an alarming and threatening rate in various regions of the world. For instance, sub-Saharan Africa has the highest informal settlement dwellers in the world with an estimate of about 199.5million people followed by South Asia (190.7million), East Asia (189.6million) and Latin America and Caribbean (110.7million) (UN Habitat, 2011, Collins et al 2013). Underpinning this tremendous trend of informal settlements in common places and common years are wide spectrum of factors. In the opinion of Tishikotshi (2009), urbanization exists side by side with an increase of poverty, rise of informal settlements and inadequate housing. While Yerach et al (2010) stated that informal settlement is caused, in many cases, by structural social inequalities, inheritance constraints, conflicts, non-pro-poor or pro-gender land policies and land administration systems that are ineffective and expensive for the end user. For instance, Nomadic settlements exemplify typical informal settlements in Nigeria. Nomadic settlements are characterized with relative absence of basic socio-economic facilities including transportation and communication routes, health services, markets, educational centers and other desirable functions of a settled community. Although, nomadic instinct, is inherent to human nature: the need to search for food, pasture and resources; the desire to travel and explore; but also to conquer and possess (Erica and Bjorn, 2012), Yet, Fulani nomads are primarily known for intrinsic migratory pattern. In fact, these groups of nomads are found in 31 out of 36 states of the Federation (Chima et al 2014). However, beyond the mobile lifestyle, nomadic cultural identity is at least bound to their animals. Therefore the basic Fulani concepts of wealth are based in their animals (Hannah, 2012). As a result, nomadic settlements evolve mainly to maximize the utility value of the specific location they are found in. To this end, the migratory pattern of Fulani nomads observably tends towards urban periphery provides desired and abundant food value for their cattle.

Nomads in Nigeria are made up of many ethnic groups, the largest being the Fulbe or Fulani; constituting over $90 \%$ (Isah, 2014). Nonetheless, countless challenges confront settlements of Fulani nomads in suitable land for livelihood. On the other hand, Blench (2010) opined that religious and cultural factors, among others, are key to peaceful relationships between Fulani nomads and the host communities but the same has become less cordial as the Fulani migrates further south. For instance, an account by Olayoku (2014) estimated about 615 violent deaths related to cattle grazing across the 36 states of Nigeria from June 2006 to May 2014. Notwithstanding the variety of social problems and lack of basic infrastructure, informal settlement seems to be most cherished among Fulani nomads.

Infrastructural development in Nigeria has long been neglected, yet attention on provision of basic facilities like health, education and water supply have largely been focused for cities at the neglect of rural areas. Most rural areas have limited access to services such as schools and health centers, and about half of the population lacks access to safe drinking water (Fakayode et al 2008). The shortfall in provision of basic infrastructure for most rural areas extends to Fulani Nomadic settlements. It is therefore pertinent to examine the available infrastructure in Fulani Nomadic settlements and their functionality.

\section{Research Methodology}

The primary sources of data collection for this study are: personal observations, reconnaissance survey, use of handheld Global Positioning System (GPS), interview, Focus Group Discussion and questionnaire administration. The first step towards actualizing the research objectives was carried out by conducting a pre-test on nomads and the selected host communities within Ogbomoso region. This helped in determining the total number of Fulani settlements (Gaa), the locational patterns of such settlements and the number of questionnaires administered.

Focus Group Discussion is the most appropriate to interrogate Fulani nomads as majority were illiterates. Consequently, the focus group created a platform for central discussion about issues on the nomads' settlement pattern, availability and accessibility of basic infrastructure. Maximum of six-eight persons constituted a focus group for optimal facilitation of the discussion and even participation of the nomads. The sessions were analyzed to reflect individual opinion

The research setting is Ogbomoso region which comprises of five local government areas; Ogbomoso North and South, Orire, Surulere and Ogo-Oluwa. All Fulani Nomadic settlements in Ogbomoso Region constitute the sample frame. The inventory of Fulani nomadic settlements indicated forty-seven (47) settlements across the study area (see Table 1). This was compiled from information given by Surulere Local Government Area Fulani Nomads Association, Ogbomoso Farmers Association and Ogbomoso South Local Government Area Cassava Farmers Association. The coordinates of all identified Fulani Nomads' Settlements were taken in order to determine their spatial patterns. Equally, the immediate native communities to all identified Fulani nomadic settlements are regarded as host communities. Meanwhile, for this study, five host communities from 
the urban parts of the study area and five host communities from the rural part of the study area were sampled in order to analyze housing characteristics of Fulani nomadic settlements across urban-rural interphase (see Table 2). However, the housing stock of selected host communities was obtained through direct counting and estimates given by the community leaders. Based on this, a total number of six hundred and forty-seven (647) residents across the selected host communities were randomly selected for questionnaire administration (see Table 3). On the other hand, one Fulani settlement was purposely selected for sampling in each host community for Focused Group Discussion in order to enhance objectivity of data collection. In each of the selected Fulani settlement, interview was conducted with the head of the clan. In case the clan head is not available, an adult is interviewed while the focus group discussion served as general platform for all available Fulanis. Content analysis using thematic approach was employed to analyze such qualitative information as, housing characteristics, availability and level of functionality of infrastructure among other relevant information. the responses from residents of host communities on the availability and functionality of infrastructure shared with Fulani Nomads were rated using Likert Scales. These include 'very functional', 'functional', 'indifferent', 'partially functional' and 'not functional' with an assigned weight of 5,4,3,2, and 1 in a decreasing order of relevance. The index developed to measure the rate of availability and functionality shared facilities was tagged Shared Facilities Index (SFI).

Likert rating Scale was equally employed to analyse respondents in the host community on functionality of shered infrastructure

Table 1: Names of Local Governments and Identified Fulani Settlements in Each Host Community

\begin{tabular}{|c|c|c|c|}
\hline $\mathbf{S} / \mathbf{N}$ & $\begin{array}{c}\text { Local Government } \\
\text { Area } \\
\end{array}$ & Host Community & Name of Identified Fulani Settlements \\
\hline 1 & Ogbomoso North & $\begin{array}{l}\text { Aaje-Ikose area } \\
\text { Iyana Olomi area }\end{array}$ & $\begin{array}{l}\text { Gaa Aaje-ikose } \\
\text { Gaa Iyana Olomi }\end{array}$ \\
\hline 2 & Ogbomoso South & $\begin{array}{l}\text { Iletitun Area } \\
\text { Ibapon Area } \\
\text { Owode Area } \\
\text { Abede Area }\end{array}$ & $\begin{array}{l}\text { Gaa Alimi, Gaa Ibrahim } \\
\text { Gaa alayun, Gaa Mohamodu. } \\
\text { Gaa owode } \\
\text { Gaa abede }\end{array}$ \\
\hline 3 & Orire & $\begin{array}{l}\text { Ajinapa } \\
\text { Tewure } \\
\text { Yawota Area }\end{array}$ & $\begin{array}{l}\text { Gaa ilomo } \\
\text { Gaa Tewure } \\
\text { Gaa Yawota Area }\end{array}$ \\
\hline 4 & Ogooluwa & $\begin{array}{l}\text { Olorunda Area } \\
\text { Esa-De Area } \\
\text { Alahausa Oloye Area } \\
\text { Oguro-ologunrun area } \\
\text { Ojotaye Area }\end{array}$ & $\begin{array}{l}\text { Gaa Olorunda } \\
\text { Gaa Esa-dee } \\
\text { Gaa Abanda } \\
\text { Gaa Keji, Gaa Olounda, Gaa Oke-high school. } \\
\text { Gaa Baba Fatimo, Gaa Tunde. }\end{array}$ \\
\hline 5 & Surulere & $\begin{array}{l}\text { Ojoku Area } \\
\text { Baba Nifa Area } \\
\text { Maya Area } \\
\text { Iyelu I Area } \\
\text { Balogun Area } \\
\text { Iyelu II Area } \\
\text { Onipaanu Area } \\
\text { Iregba Area } \\
\text { Iresadu Area } \\
\text { Elegbodo Area }\end{array}$ & $\begin{array}{l}\text { Gaa Bello, Gaa Oja-nla, Gaa Sanda, Gaa Jumbo. } \\
\text { Gaa Obo-owo } \\
\text { Gaa Isa-agba, Gaa Isa-kerere. } \\
\text { Gaa Oni-Dusi, Gaa 'Laege, Gaa Arolu, Gaa } \\
\text { ijado, Gaa alako. } \\
\text { Gaa Oseni } \\
\text { Gaa Alfa Hameed, Gaa Dotio, Gaa Elesun, Gaa } \\
\text { Mumini, Gaa Duro, Gaa Shereki. } \\
\text { Gaa Idi-Ya, Gaa Keewo, Gaa Idi-Apa, Gaa Oke- } \\
\text { ogbe, Gaa abule-Johnu. } \\
\text { Gaa Egbe } \\
\text { Gaa olokiti, Gaa Agayan. } \\
\text { Gaa Jimoh }\end{array}$ \\
\hline
\end{tabular}

Source: Author's Computation, 2015 


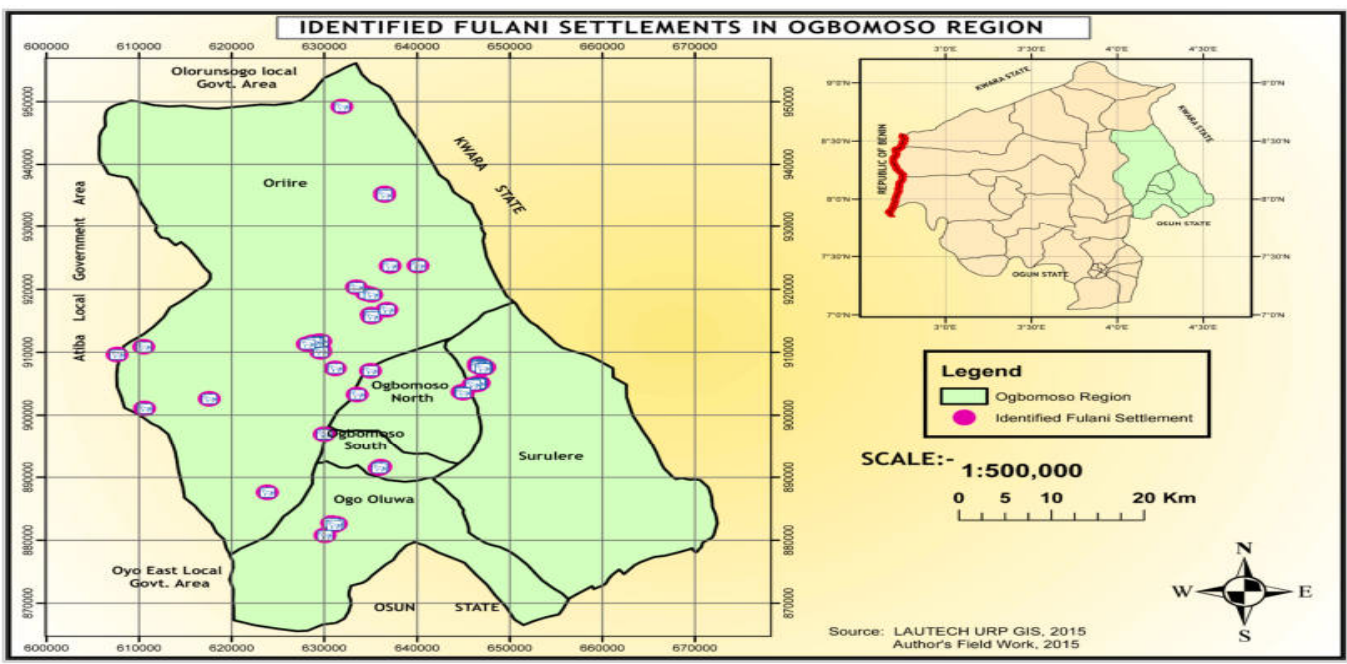

Figure 1 Fulani Settlements in Ogbomoso Region

Table 2 Selected Fulani Settlements in Each Host Community

\begin{tabular}{|c|c|c|c|c|c|}
\hline $\mathbf{S} / \mathbf{N}$ & $\begin{array}{l}\text { Local } \\
\text { Government } \\
\text { Area }\end{array}$ & $\begin{array}{l}\text { Host } \\
\text { Community }\end{array}$ & $\begin{array}{l}\text { Name of Selected } \\
\text { Fulani Settlements }\end{array}$ & $\begin{array}{l}\text { Estimated } \\
\text { Number } \\
\text { Buildings }\end{array}$ & $\begin{array}{l}\text { Number of } \\
\text { Questionnaires } \\
(\mathbf{2 0 \%})\end{array}$ \\
\hline \multirow[t]{2}{*}{1} & \multirow[t]{2}{*}{ Ogbomoso North } & Aaje-Ikose area & Gaa Bororo & 521 & 105 \\
\hline & & Iyana Olomi area & Gaa Iyana Olomi & 18 & 4 \\
\hline \multirow[t]{2}{*}{2} & \multirow[t]{2}{*}{ Ogbomoso South } & Iletitun Area & Gaa Omotunde & 42 & 9 \\
\hline & & Ibapon Area & Gaa Ibapon & 96 & 19 \\
\hline \multirow[t]{2}{*}{3} & \multirow[t]{2}{*}{ Orire } & Ajinapa & Gaa Alaya I & 496 & 99 \\
\hline & & Tewure & Gaa Ilomo & 1928 & 386 \\
\hline \multirow[t]{2}{*}{4} & \multirow[t]{2}{*}{ Ogooluwa } & Otamokun area & Gaa Otamokun & 27 & 5 \\
\hline & & $\begin{array}{l}\text { Oguro-ologunrun } \\
\text { area }\end{array}$ & Gaa Oguro & 45 & 9 \\
\hline \multirow[t]{3}{*}{5} & \multirow[t]{2}{*}{ Surulere } & Iyelu I Area & Gaa Akorede & 30 & 6 \\
\hline & & Onipaanu Area & Gaa Alata II. & 25 & 5 \\
\hline & Total & 10 & 10 & 3228 & 647 \\
\hline
\end{tabular}

Source: Author's Computation, 2015

\section{Results and Discussion}

3.1 Types

Fulani housing just as other housing types, satisfies primarily the shelter aspects of housing with an indigenous design of a cone-like shape (see plate 1) built with grass and sticks. Few Fulani settlements within urban parts of the Region undergo a more rapid process of modern housing that is houses built more sophisticatedly with building materials like corrugated iron roofing sheets, bricks, and adequate standard of window and door sizes, improved floor and wall finishing and in built bathrooms (see plate 2). While majority of Fulani nomadic settlements in the rural parts of the Region have indigenous housing type. The accounts of Focus Group Discussion on Fulani housing revealed factors, benefits and challenges of each housing type. A respondent in Gaa Alaya responded that;

"...the indigenous housing structures is most preferred by us because we are nomads".

Another respondent in Gaa Omotunde put it this way

"... We nomads need temporal structures..." 
The major problem observed of this housing type, structural collapse during rainy season due weakening of structure as result of frequent and heavy rain fall (see plate 3 ). While during dry seasons the grass roof becomes dry which must be repaired at the onset of raining season.

Nevertheless, reasons for preferred housing type for each Fulani nomad include length of stay, income, and household size. This also includes cheap availability of building materials, ease of construction and dismantling of structures especially for indigenous housing type. It is also important to note that Fulani Housing undergoes a process from indigenous housing to modern housing provided there is good economic power. It was obvious from their comments that a change of taste in housing type sets in when a nomad becomes more prosperous and intend to stay longer. For instance a respondent that;

"When we got here, we lived in indigenous housing structures

but today we are happy to be blessed with modern house. The

modern house provides more than one housing unit unlike the

indigenous housing structures..."

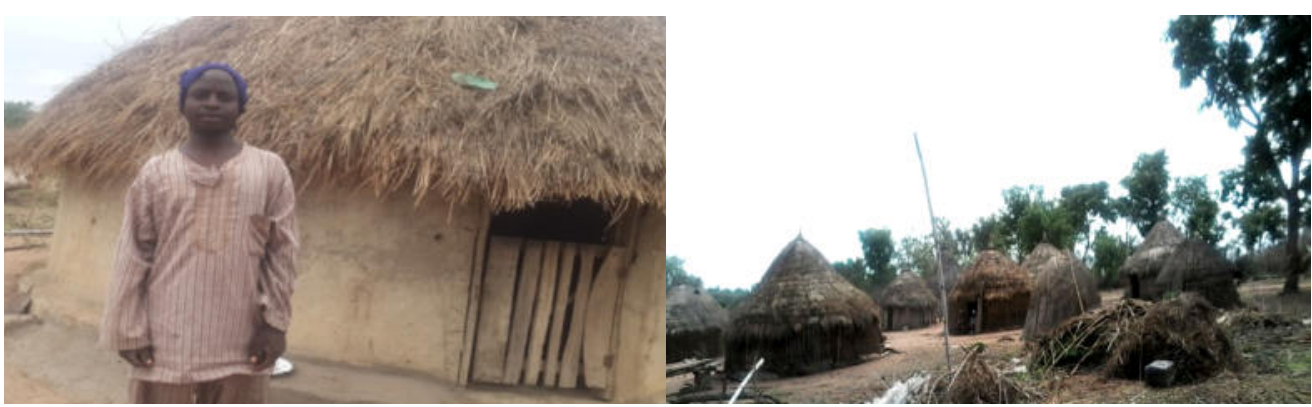

Plate 1: Indigenous Fulani Housing Type at Gaa Oguro-ologurun, Ogooluwa Local Government Area, Ogbomoso.

Source: Author's Fieldwork, 2015
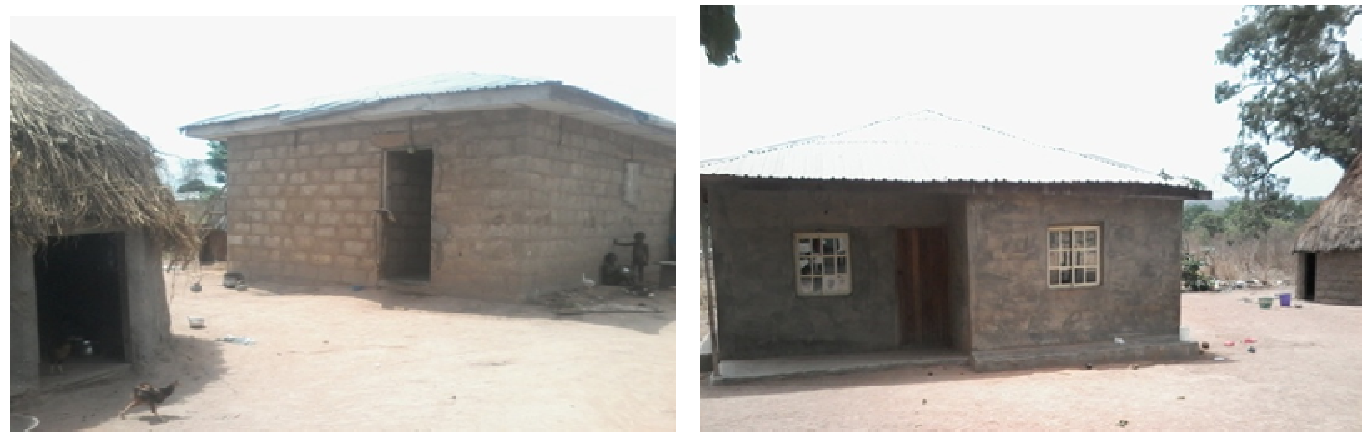

Plate 2: Modern Fulani Housing at Gaa Ibapon, Ogbomoso South Local Government Area, Ogbomoso. Source: Author's Fieldwork, 2015

\subsection{Impacts of Housing Type}

The housing type identified indicates predominance of indigenous basically for economic cost and cultural reasons. However, it implies that more grass and sticks (the building materials for indigenous housing type, (see plate 4 and 5) are explored from the surrounding bush. Meanwhile, sustainability of the environment requires that housing could be affordable, environmental friendly or community-based practices. But all attempts must be made to reduce the negative impact of house construction and domestic housing in environmental management. Gilkinson and Sexton (2007) as cited by Abraham and Albert (2013). 


\subsection{Housing Condition and Occupancy Ratio}

In this study, housing condition relates the existing state and physical characteristics of houses for Fulani Nomads within the study area. The notable physical characteristics of Fulani indigenous house structures include; absence of ceiling in all dwelling units and sub-standard window and door sizes resulting to poor ventilation (see plate 6). Others include; use of grass and planks for roof material, wall finishing, window and door materials while cattle dung for floor finishing is still widely practiced among them despite the global civilization. The health implications of poor housing condition in a similar study by Usen and Joseph (2013) are highlighted as occurrence of Asthma, Pneumonia, Cough and Bronchitis among household members.

Meanwhile, occupancy ratio measures Fulani housing quality in terms number nomads dwelling a single housing unit. This can be influenced by marriage and the presence of children. It is however, observed that Fulani housing especially for indigenous Fulani hut, usually comprises of a single dwelling unit that often satisfies the privacy aspect of housing. Especially for the family head or matured male. While mother and children often times share a dwelling unit, there is no specific number for this. In this case occapancy ratio satisfies family cohesion rather than two people per habitable room standard. This is justified in a comment made by a Fulani woman;

$$
\begin{gathered}
\text { "we feel more safe and comfortable when we sleep together } \\
\text { with our children and relations except when we have to } \\
\text { separate matured female and matured male, when family } \\
\text { sleeps together there is love." }
\end{gathered}
$$

\subsection{Impacts of Housing Condition and Occpancy Ratio}

It could be presumed that housing conditions of the nomads will have substantial impacts on the health of the residents of the whole not only the Fulani living in them. The possibility of diseases breaking out from one Fulani settlement as a result of poor housing condition and spreading out to the host communities should not be underestimated. For instance there is a link between infectious disease transmission such as tuberculosis and housing condition (WHO, 2010). Inadequate ventilation and overcrowding (through high occupancy ratio) within dwelling units increases the prevalence and transmission of tuberculosis. The concern here is, most Fulani housing units have poor ventilation (as a result of sub-standard sizes of windows and doors) and according to ACS (2007) tuberculosis is highly contagious and can spread when an infected person coughs or sneezes. This implies that an infected Fulani nomad can transmit this disease to residents of the study area. Cholera, Typhoid, Hepatitis E, Measles among others are other communicable diseases attributed to living in poor housing conditions especially when dwelling units are overcrowded.
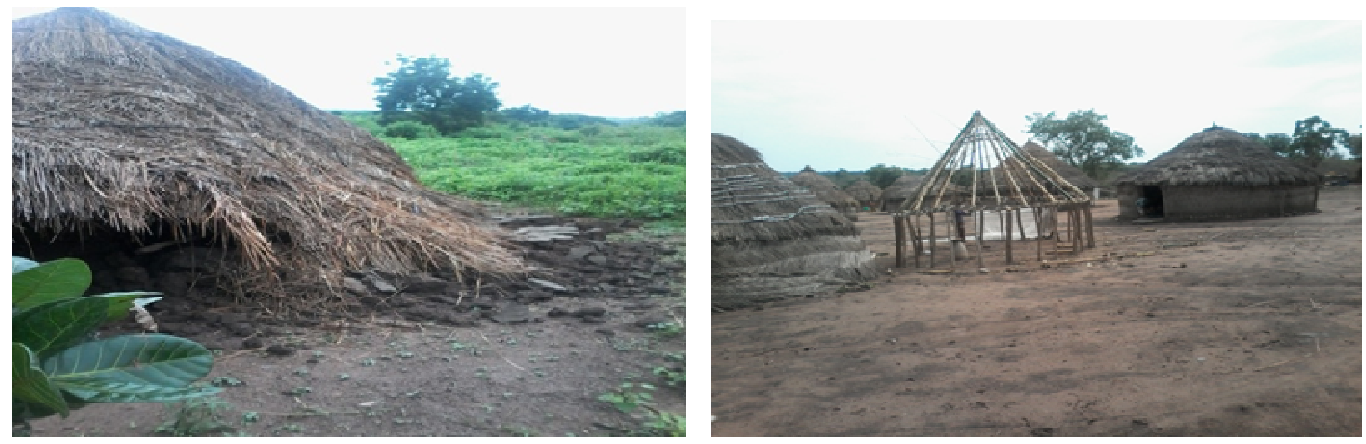

Plate 3: Collapsed Structure During Heavy Rainfall and Typical Structure Under Construction at Gaa Bororo, Ogbomoso North Local Government Area, Ogbomoso.

Source: Author's Fieldwork, 2015 

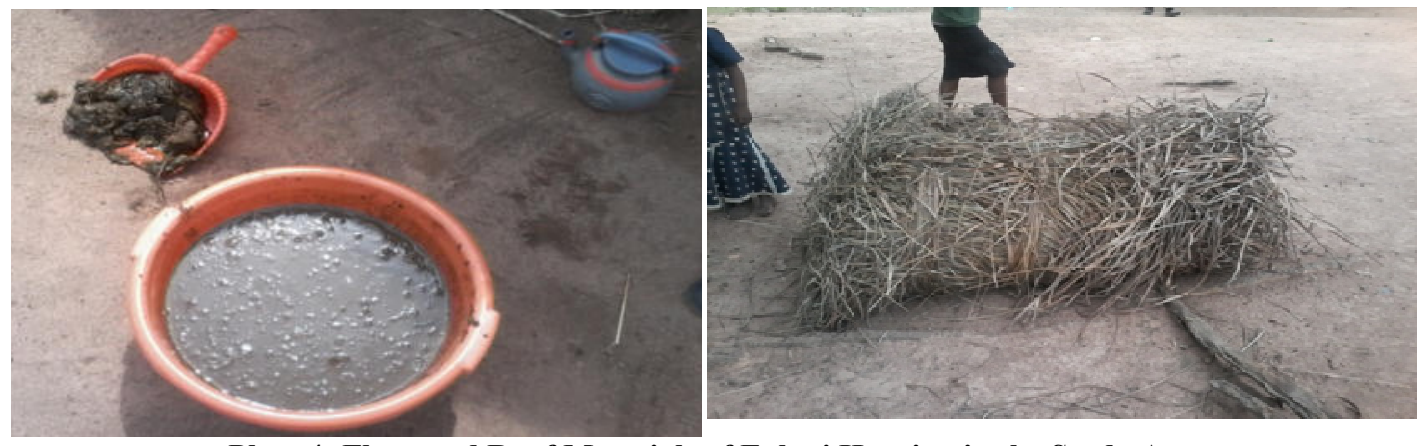

Plate 4: Floor and Roof Materials of Fulani Housing in the Study Area.

Source: Author's Fieldwork, 2015
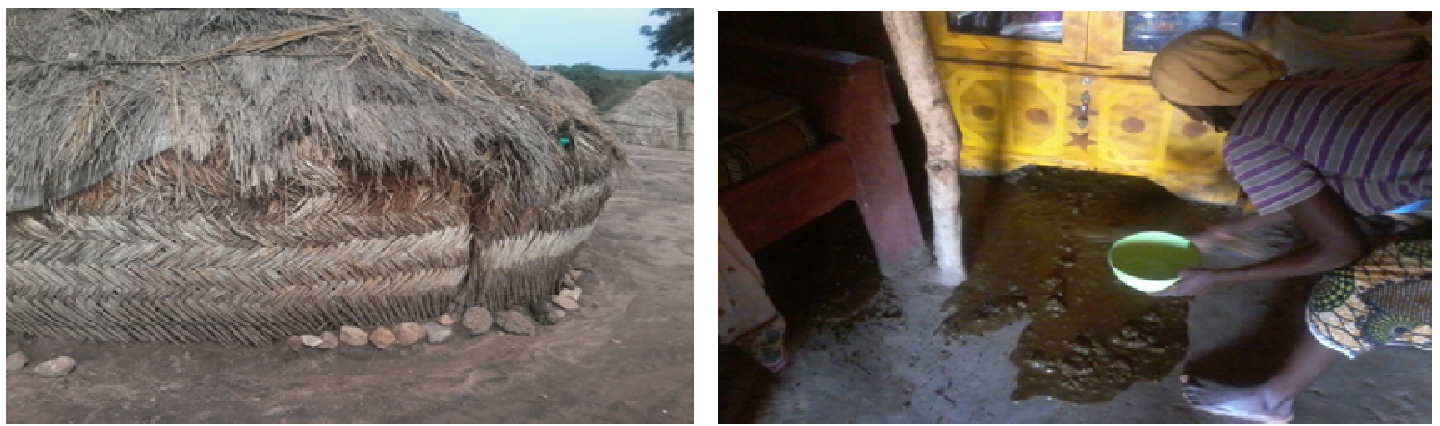

Plate 5: Wall Finishing and Floor Finishing of Fulani Structures in the Study Area Source: Author's Fieldwork, 2015
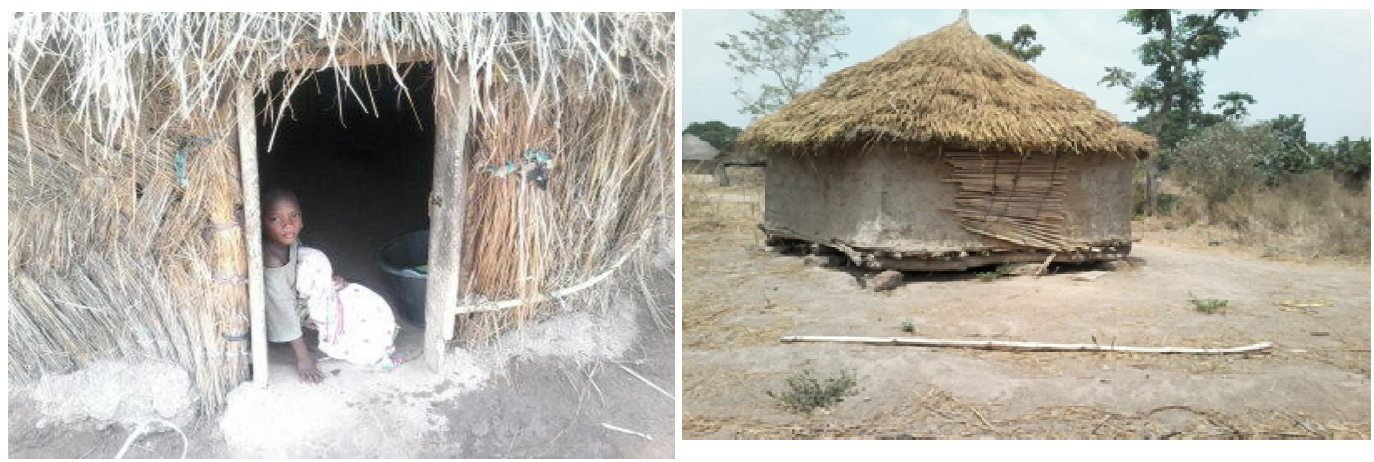

Plate 6: Door and Window Conditions of Fulani Housing at Iyana-olomi, Ogbomoso South Local Government Area, Ogbomoso.

Source: Author's Fieldwork, 2015

\subsection{Sanitary Facilities}

Every building must be designed and constructed in such a way that sanitary facilities are provided for all occupants and visitors to the building. This must be constructed in a form that allows convenience of use without constituting threat to the health and safety of occupants or visitors. Also, the adequacy of sanitary facilities is two dimensional that is availability and accessibility based on the number of persons in such dwelling units. In the study area, observations indicated poor state of sanitary facilities in terms of availability and accessibility. On this premise, major sanitary facilities understudied are, toilet, bathroom, waste disposal system, and water supply.

Generally and specifically, for all Fulani settlements within the urban and rural areas of Ogbomoso region, toilet facility is completely lacking. Moreover, open refuse dump is the mostly adopted method of waste disposal in all sampled Fulani settlements. The reports of various Focus Group Discussion sessions made the author to realize that most Fulani nomads are not environmental conscious and therefore do not see anything 
wrong in open refuse dump and open defecation. Also, the health implications of such poor sanitary practices is unknown to them.

\author{
For instance a respondent opined that \\ "... we are surrounded by bushes we do not \\ need to waste money to dig toilets..." \\ Another respondent stated that \\ "...We have prevented diseases by dumping the \\ waste outside our dwelling, and we sweep \\ everywhere daily to prevent any form of disease".
}

This level of ignorance on importance of environmental sanitation and practices among the nomads can be linked to illiteracy and type of occupation, that probably are fundamental to such psychological belief. This is similar to the opinion of Babalola et al (2010) that the illiterates are often more interested in daily survival than environmental management. However, this lack of interest and awareness often lead to more reckless environmental behaviour which in turn breeds more environmental problems.

Further observations on water provision for Fulani settlements revealed that natural water bodies like rivers and streams are the main source of water supply (see plate 7). These are often many kilometers away from the settlements. Also in raining season, rain water is harvested for domestic use in Fulani settlements. Similarly, more than average number of nomads that participated in different Focus Group discussion expressed the difficulty encountered in water provision.

A piece from one of the sessions tend to give the scenario of the subject.
"...Water is a serious problem here, we drink from streams and rivers that are very far from here. These water bodies also dry up in dry season increasing the difficulty of getting water in peak dry seasons, we can go many days without washing our clothes and taking bath".

In spite of the water provision problem, majority of the nomads did not believe in individual or communal efforts to provide portable water is a good idea.

This is reflected in the response of one Fulani clan head

"...We cannot provide water for ourselves, it is expensive and besides we are nomads that can leave this place for another anytime, such an investment will be a waste in the long run".

It could be observed as well that the bathroom facilities are predominantly outdoor (see plate 8) and shared among different dwelling units while the kitchen facilities could be indoor or outdoor as preferred but in any case are poorly furnished and substandard (see plate 9).
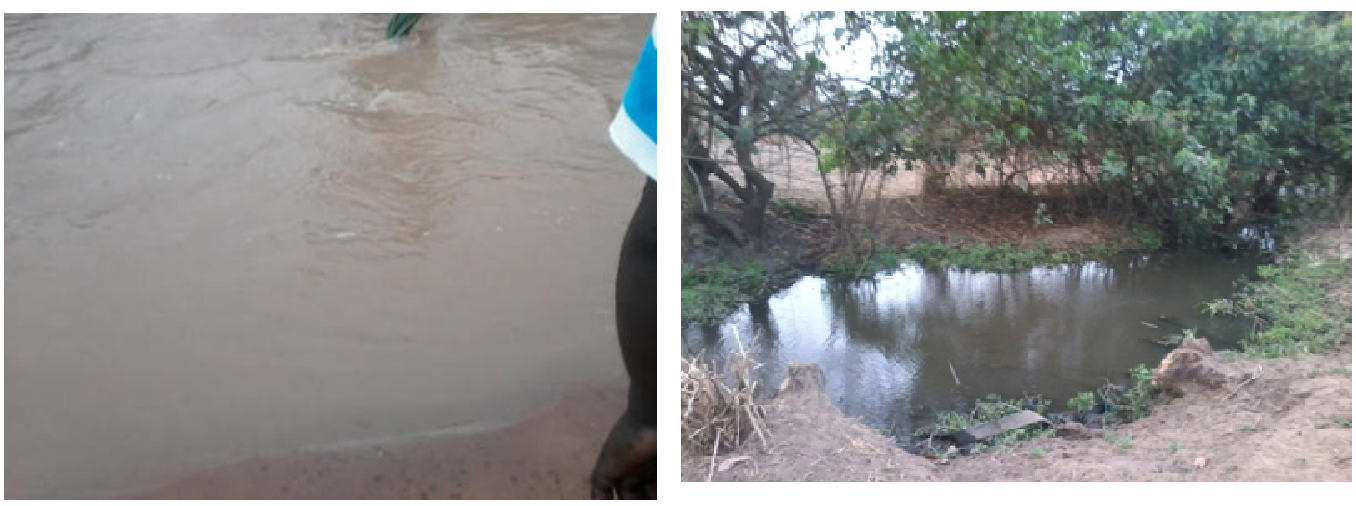

\footnotetext{
Plate .7a: Sources of Water Supply at Gaa Alaya Plate 7b: Sources of Water Supply at Gaa Ilomo Orire Local Government Area, Ogbomoso Source: Author's Fieldwork, 2015
} 


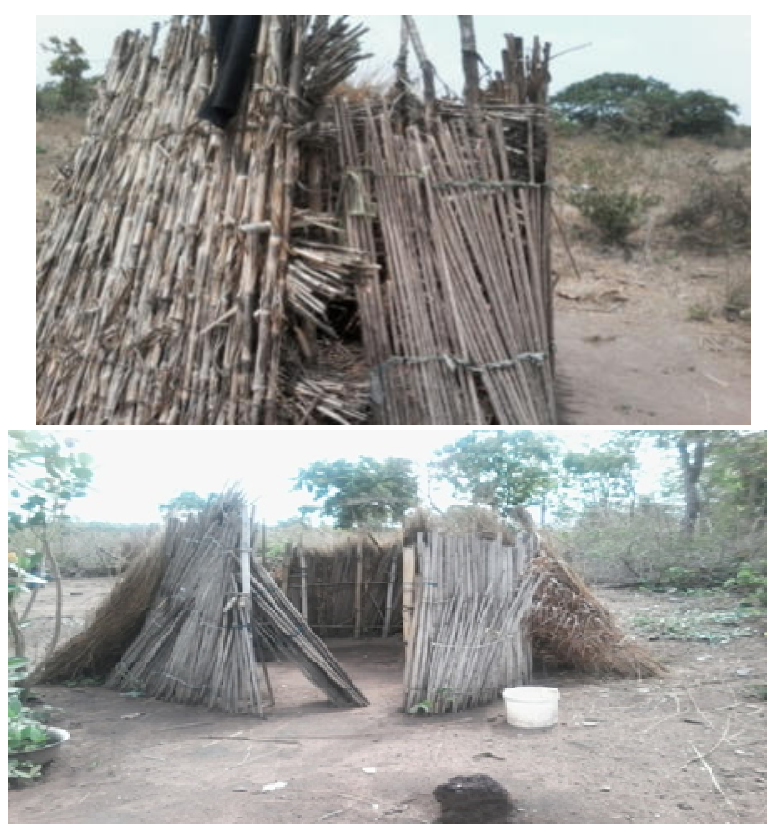

Plate 8: Outdoor Bathroom facilities at Gaa Iyelu I, Surulere Local Government Area, Ogbomoso. Source: Author's Fieldwork, 2015
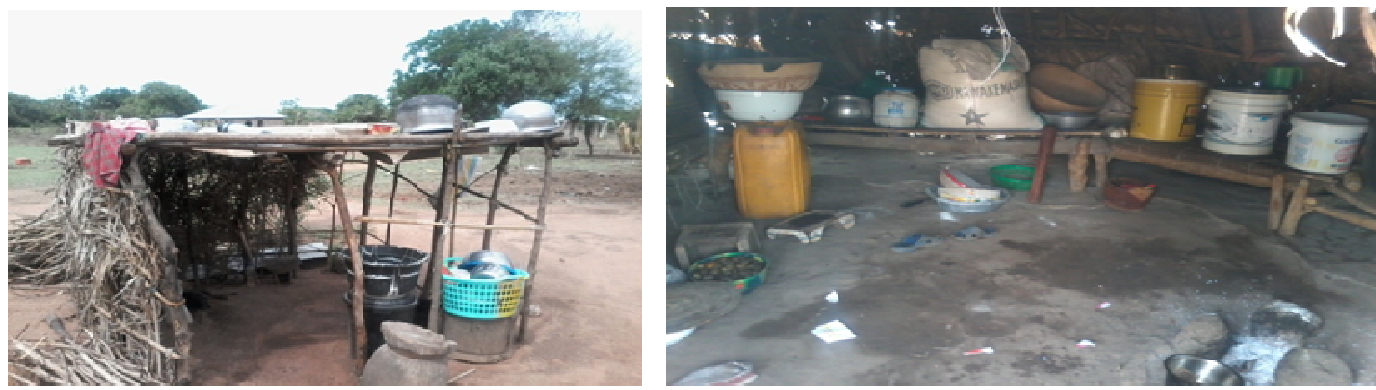

Plate 9: Indoor and Outdoor Kitchen Facilities at Gaa Alaya, Orire Local Government Area, Ogbomoso. Source: Author's Fieldwork, 2015

\subsection{Impacts of Conditions of Sanitary Facilities}

The risks associated with poor sanitary facilities are multiple, however the risk of ingestion of unsafe water by residents of whole study area through inadequate personal and domestic hygiene of the nomads and agricultural practices (polluting of water bodies by their cattle) worth assessing. It could be argued that with lack of services to provide safe drinking water and adequate sanitation, and the lack of solid waste management services in one Fulani community, the whole Ogbomoso region is prone to faecal-oral diseases. According to Brain (2012), Faecal-oral disease is transmitted when a susceptible person swallows viruses or bacteria found in the stool of another person or animal. This occurs mostly through drinking and to some extent bathing with contaminated water or foodborne transmission (Brain 2012).

\subsection{Factors for Air and Green Spaces}

Although, Fulani structures are often clustered within a settlement yet adequate air space is maintained in all Fulani settlements coupled with presence of greeneries around their settlements. These are indicators to good environmental quality. Observations on location of Fulani Settlements within the study area revealed that majority of them are located in jungles, many meters away from the host communities in order to keep their animals away from intruding peoples' properties. Futhermore, such area provide large grazing land and settlement developing. Consequently, the settlements are well spaced (giving adequate air space between buildings) and surrounded with beautiful vista of trees and grasses (see plate 10). 


\subsection{Impacts of Air and Green Spaces}

The presence green spaces within Fulani settlements of Ogbomoso region had direct effects on microclimate of the region. According to Ephraim and Mbina (2014) greening offer improvement in air, water, and land resources by absorbing air pollutant, increasing water catchment and flood plain surfaces, and stabilizing soils.
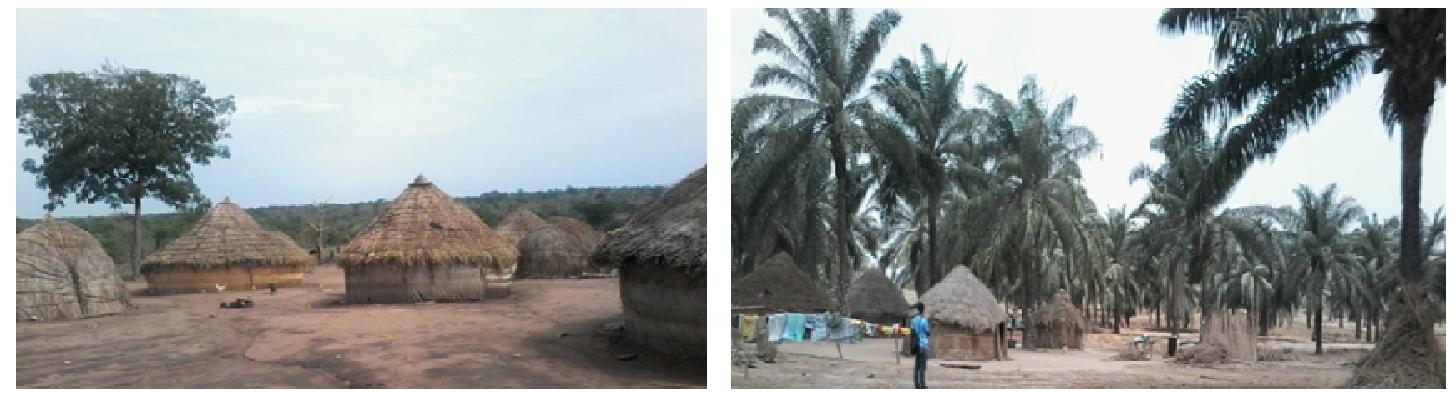

Plate 10: Air And Green Spaces at Gaa Alata, Surulere Local Government Area. Source: Author's Fieldwork, 2015

\subsection{Responses on Focus Group Discussions on Infrastructure Availability and Functionality}

Based on the information collected through focus group discussions at Gaa Alaya II, Ajinapa, Orire Local Government Area and Gaa Omotunde, Iletitun area, Ogbomoso South Local Government Area, it could be observed that there is gross inadequacy in facilities provisions for the sampled Fulani Settlements. However, Fulani Nomads have access to share any available facilities with the residents of the host communities. In this suit, the following discussions report the availability and functionality of different facilities;

\subsubsection{Availability and Functionality of Educational Facilities}

"....There is a nomadic school for our children (see plate 11) but the school is not well staffed, we observed many of our children cannot actually read and write in English. This is very sad, because now that we value education, the quality is too poor".

".... The only school in this community serve us and the residents of host community. Even the classrooms are not in good condition. Therefore, we urge the government to provide basic amenities for us, it is our rights, they should stop remembering us only during election period".

\subsubsection{Availability and Functionality of Market Facilities}

"...About four years ago the state government built a cattle market at Ilomo, which is highly patronized by Fulani Nomads and the residents of the host communities. We need more markets for better economic development."

\subsubsection{Availability and Functionality of Water Facilities}

"...Water supply to Fulani community has remained an ageless problem not only peculiar to this place alone but all over. Our women travel long distance to fetch water for domestic use and drinking, same thing for the cattle we take them far into the bush to drink water".

....."There is only one bole hole water supply for the host community and fulanis in Ile-titun, and one can only fetch on Saturdays if you go there early enough, the functionality of this facility is worse during dry season (see plate 12)".

\subsubsection{Availability and Functionality of Health Care Facilities}

"..There is one primary health care very close to us here but has remained non functional for many months now (see plate 13)".

"... No separate health care facility for nomad we patronize the affordable ones within the host community or use traditional medicine to treat ourselves (see plate 14).

\subsubsection{Availability and Functionality of Road}

"The government do not care that we do not have good access roads, we are only linked up with host communities by footpaths."

The above discussions have shown that the most Fulani settlements depend on their host communities for facilities provisions. This has compounded the problems of inadequacies, availability and functionality of facilities in the study area. 


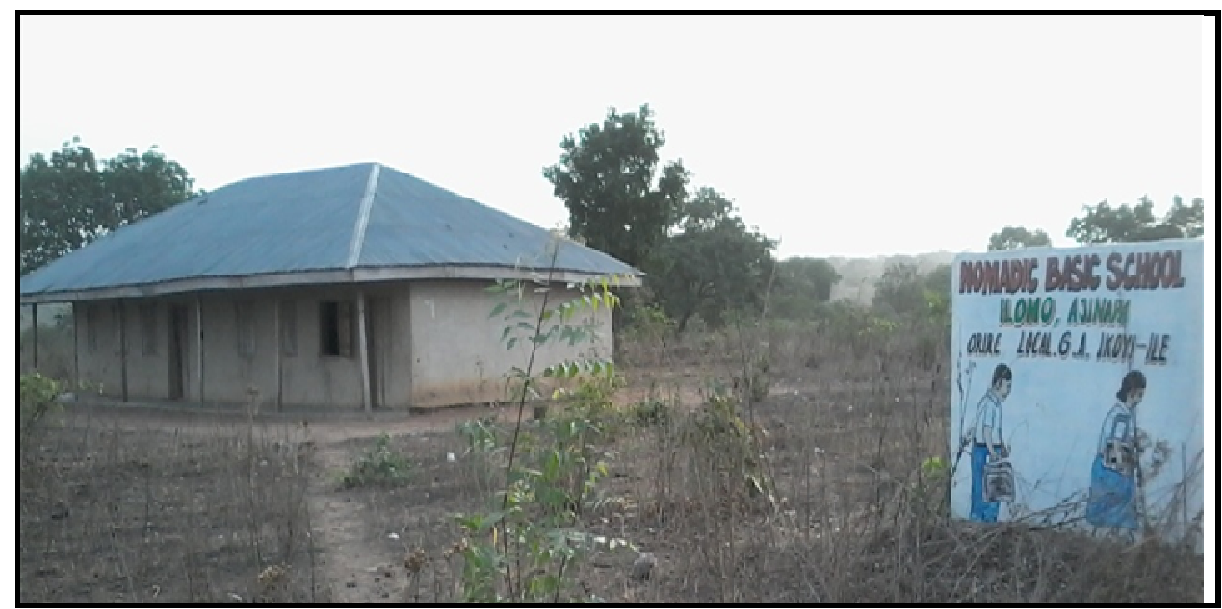

Plate 11: Nomadic School At Ilomo, Orire Local Government Area, Ogbomoso Source: Author's Fieldwork, 2015

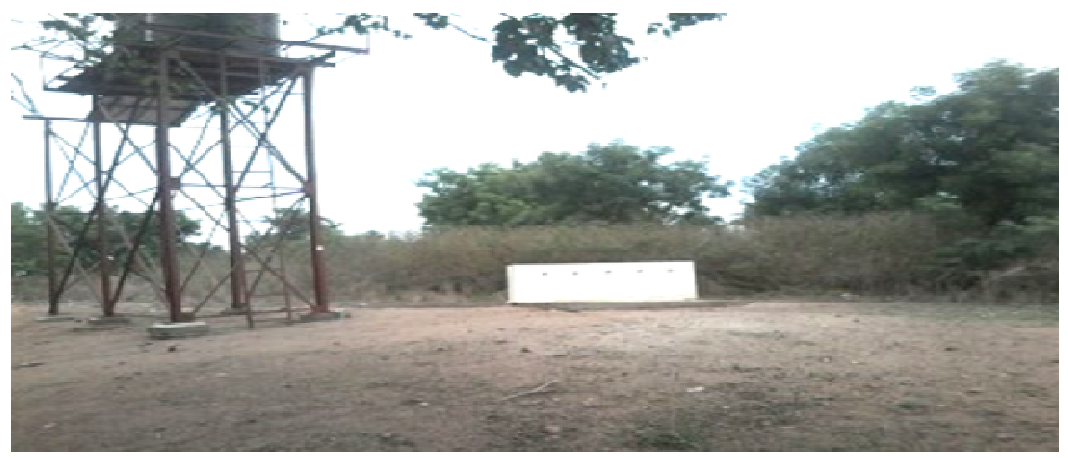

Plate 12: Shared Water Facility at Ile -titun, Ogbomoso South Local Government Area, Ogbomoso.

Source: Author's Fieldwork, 2015

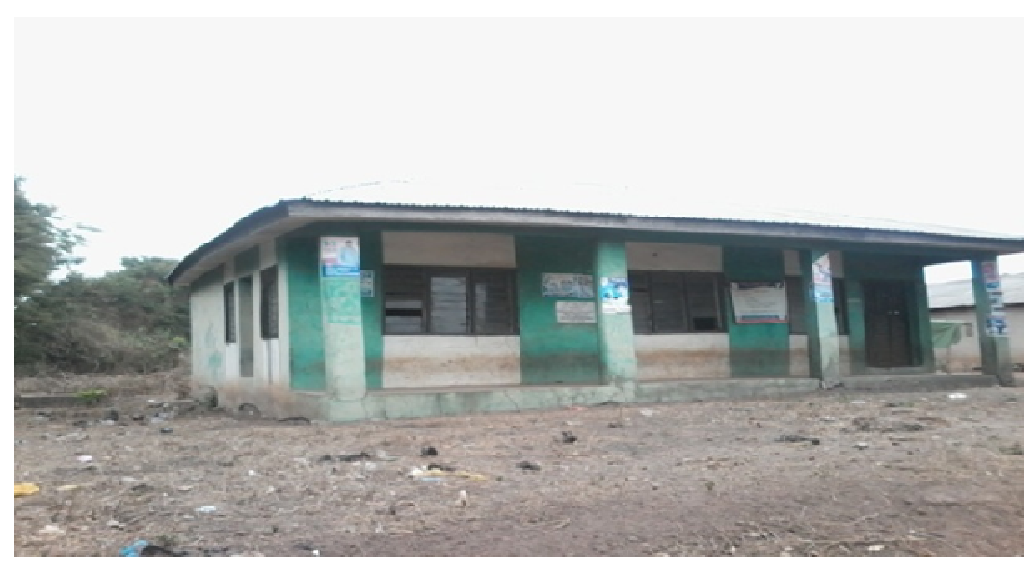

Plate 13: Shared Health Facility at Iyelu II, Surulere Local Government Area, Ogbomoso. Source: Author's Fieldwork, 2015 


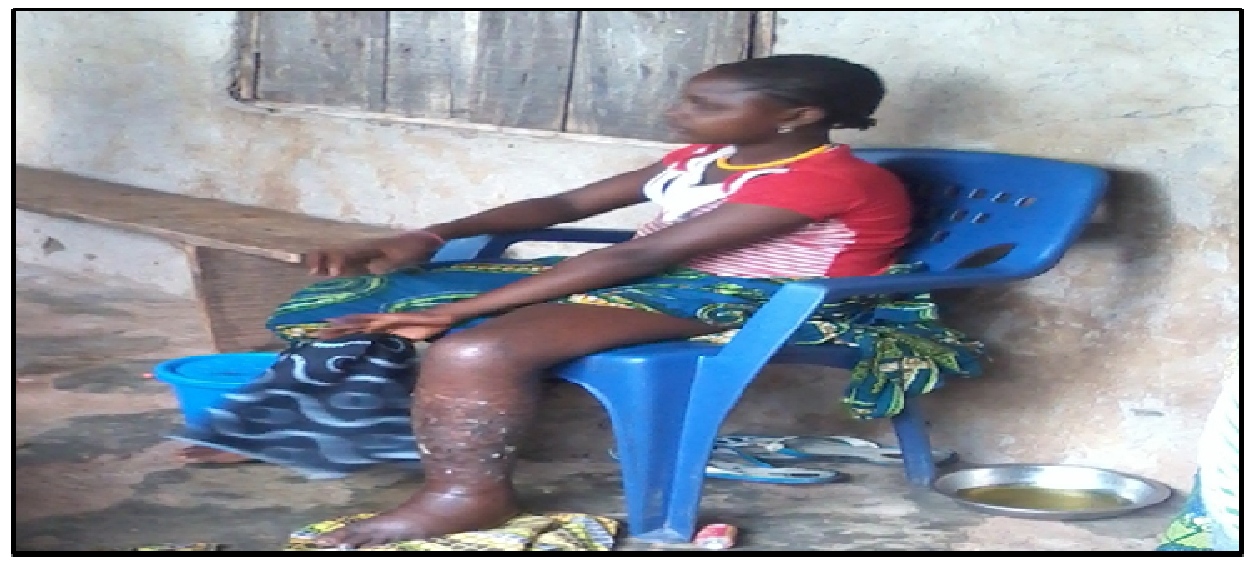

Plate 14.: Accident Victim Deprived of Medical Care at Gaa Iyelu II, Surulere Local Government Area, Ogbomoso.

\subsection{Residents' View on Availability and Functionality of Shared Infrastructure Among Fulani Nomads and the Host Communities}

From Table 3, the result of findings reveals that there is a close link with facilities available and their level of functionality. For instance, majority (98.8\%) of respondents affirmed that road and primary school $(98.1 \%)$ are virtually available in the study area. This is followed by respondents a little above the average $(52.6 \%)$ who affirmed that market as a unit of business transaction is also available in the study area. This is also reflected in the level of functionality of these shared facilities where the larger proportion of respondents perceived road to have highest functionality with an index of 3.40, followed by primary school (SFI 3.16) and market facilities with an index of 2.67. It can be inferred that availability and functionality of shared facilities such as road, primary school and market are presently solving inadequacy problem of the same facilities in Fulani settlements of the study area. This is because they recorded high positive deviation about the mean. However, the sustainability of these shared facilities may overtime become imbalance. This could be corroborated by the assertion of Fakayode et al (2008) that insensitivity of the Nigerian government to provide adequate basic infrastructure may have informed the stress on the available ones leading to eventual breakdown in many instances.

Further analysis as shown in Table 3 presents a fewer proportion of perceived availability of other facilities such as health center (35.9\%), secondary school $(22.3 \%)$, water supply $(30.3 \%)$, electricity $(1.2 \%)$ and public toilet $(0.2 \%)$. This also corresponds to their perceived level of functionality with indices of $1.67,1.45$, $1.40,1.03$ and 1.00 respectively. When compared with the mean, facilities like health center, secondary school, water supply, electricity and public are relatively low in availability and functionality. Consequently, there are serious implications on the quality of life for Fulani nomads and the residents of host communities. The variance is 0.090885 and standard deviation is 0.9533 with a coefficient of standard to be $48.39 \%$. 
Table 3 : Responses on Availability and Functionality of Shared Facilities among Fulani Nomads and Host Communities

\begin{tabular}{|c|c|c|c|c|c|c|c|c|c|c|}
\hline \multirow[t]{3}{*}{ Shared Facilities } & \multicolumn{2}{|l|}{ Availability } & \multicolumn{4}{|c|}{ Functionality } & \multicolumn{4}{|c|}{ Weighed Values } \\
\hline & \multirow[t]{2}{*}{ Available(\%) } & \multirow[t]{2}{*}{ Not available (\%) } & VF & $\mathbf{F}$ & PF & NF & \multirow[t]{2}{*}{ SWV } & \multirow[t]{2}{*}{ SFI } & \multirow[t]{2}{*}{ D } & \multirow[t]{2}{*}{$\mathbf{D}^{2}$} \\
\hline & & & 4 & 3 & 2 & 1 & & & & \\
\hline Road & $639(98.8 \%)$ & $8(1.2 \%)$ & 313 & 290 & 36 & 8 & 2,202 & 3.40 & 1.43 & 2.0449 \\
\hline Primary School & $635(98.1 \%)$ & $12(1.9 \%)$ & 381 & 3 & 250 & 12 & 2,045 & 3.16 & 1.19 & 1.4161 \\
\hline Market & $340(52.6 \%)$ & $307(47.4 \%)$ & 339 & 1 & - & 307 & 1,729 & 2.67 & 0.7 & 0.4900 \\
\hline & $232(35.9 \%)$ & $415(64.1 \%)$ & 77 & 37 & 124 & 415 & 1,082 & 1.67 & -0.3 & 0.9000 \\
\hline $\begin{array}{l}\text { Health Center } \\
\text { Secondary School }\end{array}$ & $144(22.3 \%)$ & $503(77.7)$ & 1 & 143 & - & 503 & 936 & 1.45 & -0.52 & 0.2704 \\
\hline Water Supply & $196(30.3 \%)$ & $451(69.7 \%)$ & 24 & 66 & 106 & 451 & 909 & 1.40 & -0.57 & 0.3249 \\
\hline Electricity & $8(1.2 \%)$ & $639(98.8 \%)$ & 2 & 6 & - & 639 & 665 & 1.03 & -0.94 & 0.8836 \\
\hline Public Toilet & $1(0.2 \%)$ & $646(99.8 \%)$ & 1 & - & - & 646 & 650 & 1.00 & -0.97 & 0.9409 \\
\hline
\end{tabular}

$*$ Mean $=1.97$

Source: Author's Fieldwork, 2015

\section{Conclusion and Recommendation}

The study concludes that informal settlement is an attribute of nomads. This manifested in spatial manifestation of nomadic settlement in Ogbomoso region. However, this study justified that that infrastructure within the region are mostly shared with the host community. Some of the facilities were not readily available for use and not functional. The study therefore recommends development of Fulani Housing Scheme through Land acquisition and layout design. Quantitative and qualitative residential development should be facilitated. Building standards and land use zoning laws should be enforced. Coupled with this, there should be adequate provision of basic infrastructural facilities. This should be accessible, functional and regularly maintained. If these recommendations are fully implemented, the livability of Fulani nomadic will be improved and sustained.

\section{REFERENCES}

Abraham T. and Albert A. (2013): Sustainable Housing Supply in Nigeria through the use of Indigenous and Composite Building Materials, Civil and Environmental Research, Vol.3 No.1.

Advisory Committee Statement (2007): Housing Conditions that serve as RISK factors for Tuberculosis Infection and Disease, Canada Communicable Disease report, Public health Agency of Canada, ACS 9.

Babalola Y., Babalola A. and Okhale F. (2010): Awareness and Accessibility of Environmental Information in Nigeria: Evidence from Delta State, Library Philosophy and Practice, available online@ http: //www.webpage.uilaho.edu/ mbolin, babalola-babalola- okhlae.html

Bassett E. Sumila G. Catherine F. and Sylvie D. (2003): Informal Settlement Upgrading in Sub- Saharan Africa: Retrospective and Lesson Learned

Blench R. (2010): Conflict between Pastoralists and Cultivators in Nigeria, Kay William Educational Foundation Cambridge, Available onlinewww.rogerbtench.infor/RBOP.htm

Brain R. (2012): Preventing the Transmission of Faecal-oral Disease, Water, Engineering and Developmental Center, Leicestershire, United Kingdom.

Chima I., Ugwegbulam C. and Chinwe O (2014): Counseling for Effective Management of Nomadic Education In Nigeria, Higher Education of Social Science, Vol 6, No. 1, pp 10- 14.

Collins A., Antwi K. and Acheampong P. (2013): Behavioural Dimension of the Growth of Informal Settlements in Kumasi City, Ghana, Research on Humanities and Social Sciences, Vol 3, No 12. 
Erica R. and Bjorn F. (2012): Theories And Typologies Of Migration An Overview And A Primer, Willy Brandt Series Of Working Papers In International Migration And Ethnic Relations, Malino Institute For Studies Of Migration, Sewden.

Erica R. and Bjorn F. (2012): Theories And Typologies Of Migration An Overview And A Primer, Willy Brandt Series Of Working Papers In International Migration And Ethnic Relations, Malino Institute For Studies Of Migration, Sewden.

Fakayode B., Omotesho O., Tsoho A., and Ajayi P. (2008): An Economic Survey of Rural Infrastructure and Agricultural Production Profile in Nigeria, European Journal of Social sciences, Vol. 7, No 2.

Fekade, W. (2000): Deficits of Formal Urban Land Management and Informal Responses Under Rapid Urban Growth, An International Perspective, Habitat International, 24(2), 127- 150.

Fikreselassie K. (2011): Modeling Informal Settlement In Dares Salam, Tanzania, A Master of Science Thesis Submitted To The Faculty Of Geo-Information Science And Earth Observation, University of Twente.

Gilkinson, N. and Sexton, M., (2007): Delivering Sustainable Homes; Meeting Requirements: a Research Agenda; Proceedings of XXXV IAHS World Congress on Housing Science, Melbourne, Australia, pp4-7.

Hannah R. (2012): Implications of Land Development on Nomadic Pastoralism: Ecological Relaxation and Biosocial Diversity in Human Population, Scripps Senior Theses, paper 68.

Isah M. (2014): No Retreat No Surrender Conflict For Survival Between Fulani Pastoralists And Farmers In Northern Nigeria, European Scientific Journal, Vol.8 No.1.

Olayoku P. (2014): Trends and Patterns of Cattle Grazing and Rural Violence in Nigeria (2006- 2014), IFRANIGERIA Working papers series, No. 34.

Sietchiping, R (2005): Prospective Slum Policies Conceptualizing and Implementation of a Proposed Informal Settlement Growth Model Paper Presented at the Third Urban Research Symposium on Land "Development, Urban Policy and Poverty Reduction" Brasilia, DF Brazil

Tshikotshi V. (2009): The Challenges Of Eradicating Informal Settlement In South Africa By 2014: The Case Of Seraleng Sustainable Human Settlement, Reistenburg Local Municipality, North West Province; A Master Thesis Submitted To Faculty Of Engineering And Built Environment, University Of Witwatersrand, Johannesburg, South Africa.

UN-HABITAT. (2003): The challenges of slums: Global Report on Human Settlement, Earth scan, London United Kingdom.

UN-HABITAT (2011): Practical guide for conducting: housing profiles, UN-Habitat Nairobi, Kenya.

Usen U. and Joseph U. (2013): Housing Conditions and Health in Nigeria: A study of Akwa Ibom State, Research on Humanities and Social Sciences, Vol.3, No 18.

Victor E. (2007): Modernizing the Informal Sector, Journal of Economic and Social Affairs, DESA Working Paper No.42.

World Health Organization (2004): Reviews of Evidence in History and Health: Background Department. Budapest Fourth Ministerial Conference on Environment and Health.

World Health Organization (2010): Healthy Housing; Expert call for International Guidelines at International Consultation of 40 experts Heild at Geneva 13-15 October 2010.

Yerach D., Paul K., Rafic K., Robin M., Hartmut M. and Chryssy A. (2010): Rapid Urbanization and Mega Cities; The Need For Spatial Information Management, The International Federation Of Surveyors, Copenhagen, Denmark. 